\title{
Form and Aging of Plutonium in Savannah River Site Waste Tank 18
}

D. T. Hobbs

February 2012

Savannah River National Laboratory Savannah River Nuclear Solutions, LLC Aiken, SC 29808

Prepared for the U.S. Department of Energy under contract number DE-AC09-08SR22470. 
SRNL-STI-2012-00106

Revision 0

\section{DISCLAIMER}

This work was prepared under an agreement with and funded by the U.S. Government. Neither the U.S. Government or its employees, nor any of its contractors, subcontractors or their employees, makes any express or implied:

1. warranty or assumes any legal liability for the accuracy, completeness, or for the use or results of such use of any information, product, or process disclosed; or

2. representation that such use or results of such use would not infringe privately owned rights; or

3. endorsement or recommendation of any specifically identified commercial product, process, or service.

Any views and opinions of authors expressed in this work do not necessarily state or reflect those of the United States Government, or its contractors, or subcontractors.

\section{Printed in the United States of America}

Prepared for

U.S. Department of Energy 
Keywords: plutonium hydroxide, plutonium oxide, amorphous, coprecipitated

Retention: Permanent

\section{Form and Aging of Plutonium in Savannah River Site Waste Tank 18}

D. T. Hobbs

February 2012

Savannah River National Laboratory Savannah River Nuclear Solutions, LLC Aiken, SC 29808

Prepared for the U.S. Department of Energy under contract number DE-AC09-08SR22470. 


\section{REVIEWS AND APPROVALS}

AUTHOR:

D. T. Hobbs, Separations and Actinide Science Programs

Date

TECHNICAL REVIEW:

S. H. Reboul, Process Technology Programs

Date

APPROVAL:

S. D. Fink, Manager

Date

Separations and Actinide Science Programs

S.L. Marra, Manager

Date

Environmental \& Chemical Process Technology Research Programs

K. H. Rosenberger, Manager

Date

SRR Closure and Disposal Assessment 


\section{SUMMARY}

This report provides a summary of the effects of aging on and the expected forms of plutonium in Tank 18 waste residues. The findings are based on available information on the operational history of Tank 18, reported analytical results for samples taken from Tank 18, and the available scientific literature for plutonium under alkaline conditions. These findings should apply in general to residues in other waste tanks. However, the operational history of other waste tanks should be evaluated for specific conditions and unique operations (e.g., acid cleaning with oxalic acid) that could alter the form of plutonium in heel residues. Based on the operational history of other tanks, characterization of samples from the heel residues in those tanks would be appropriate to confirm the form of plutonium.

During the operational period and continuing with the residual heel removal periods, $\mathrm{Pu}(\mathrm{IV})$ is the dominant oxidation state of the plutonium. Small fractions of $\mathrm{Pu}(\mathrm{V})$ and $\mathrm{Pu}(\mathrm{VI})$ could be present as the result of the presence of water and the result of reactions with oxygen in air and products from the radiolysis of water. However, the presence of $\mathrm{Pu}(\mathrm{V})$ would be transitory as it is not stable at the dilute alkaline conditions that currently exists in Tank 18.

Most of the plutonium that enters Savannah River Site (SRS) high-level waste (HLW) tanks is freshly precipitated as amorphous plutonium hydroxide, $\mathrm{Pu}(\mathrm{OH})_{4(\mathrm{am})}$ or hydrous plutonium oxide, $\mathrm{PuO}_{2 \text { (am,hyd) }}$ and coprecipitated within a mixture of hydrous metal oxide phases containing metals such as iron, aluminum, manganese and uranium. The coprecipitated plutonium would include $\mathrm{Pu}^{4+}$ that has been substituted for other metal ions in crystal lattice sites, $\mathrm{Pu}^{4+}$ occluded within hydrous metal oxide particles and $\mathrm{Pu}^{4+}$ adsorbed onto the surface of hydrous metal oxide particles. The adsorbed plutonium could include both inner sphere coordination and outer sphere coordination of the plutonium. $\mathrm{PuO}_{2(\mathrm{am}, \mathrm{hyd})}$ is also likely to be present in deposits and scales that have formed on the steel surfaces of the tank. Over the operational period and after closure of Tank 18, Ostwald ripening has and will continue to transform $\mathrm{PuO}_{2(\mathrm{am}, \mathrm{hyd})}$ to a more crystalline form of plutonium dioxide, $\mathrm{PuO}_{2(\mathrm{c})}$.

After bulk waste removal and heel retrieval operations, the free hydroxide concentration decreased and the carbonate concentration in the free liquid and solids increased. Consequently, a portion of the $\mathrm{PuO}_{2(\mathrm{am}, \mathrm{hyd})}$ has likely been converted to a hydroxy-carbonate complex such as $\mathrm{Pu}(\mathrm{OH})_{2}\left(\mathrm{CO}_{3}\right)_{(\mathrm{s})}$. or $\mathrm{PuO}\left(\mathrm{CO}_{3}\right) \mathrm{xH}_{2} \mathrm{O}_{(\mathrm{am})}$. Like $\mathrm{PuO}_{2(\mathrm{am}, \mathrm{hyd})}$, Ostwald ripening of $\mathrm{Pu}(\mathrm{OH})_{2}\left(\mathrm{CO}_{3}\right)_{(\mathrm{s})}$ or $\mathrm{PuO}\left(\mathrm{CO}_{3}\right) \mathrm{xH}_{2} \mathrm{O}_{\text {(am) }}$ would be expected to occur to produce a more crystalline form of the plutonium carbonate complex. Due to the high alkalinity and low carbonate concentration in the grout formulation, it is expected that upon interaction with the grout, the plutonium carbonate complexes will transform back into plutonium hydroxide.

Although crystalline plutonium dioxide is the more stable thermodynamic state of $\mathrm{Pu}(\mathrm{IV})$, the low temperature and high water content of the waste during the operating and heel removal periods in Tank 18 have limited the transformation of the plutonium into crystalline plutonium dioxide. During the tank closure period of thousands of years, transformation of the plutonium into a more crystalline plutonium dioxide form would be expected. However, the continuing presence of water, reaction with water radiolysis products, and low temperatures will limit the transformation, and will likely maintain an amorphous $\mathrm{Pu}(\mathrm{OH})_{4}$ or $\mathrm{PuO}_{2 \text { (am,hyd) }}$ form on the surface of any crystalline plutonium dioxide produced after tank closure. X-ray Absorption Spectroscopic (XAS) measurements of Tank 18 residues are recommended to confirm coordination environments of the plutonium. If the presence of $\mathrm{PuO}\left(\mathrm{CO}_{3}\right)_{(\mathrm{am} \text {,hyd) }}$ is confirmed by $\mathrm{XAS}$, it is recommended that experiments be conducted to determine if plutonium carbonates are transformed back into $\mathrm{PuO}_{2(\mathrm{am}, \text { hyd) }}$ upon contact with grout. 


\section{LIST OF ABBREVIATIONS}

$\begin{array}{ll}\text { ADMP } & \text { Advanced Design Mixer Pump } \\ \text { HLW } & \text { High-Level Waste } \\ \text { PA } & \text { Performance Assessment } \\ \text { SRNL } & \text { Savannah River National Laboratory } \\ \text { SRS } & \text { Savannah River Site } \\ \text { UHP } & \text { Ultra-high pressure } \\ \text { XAS } & \text { X-ray Absorption Spectroscopy }\end{array}$




\section{Background $^{1,2}$}

Savannah River Site (SRS) Tank 18 was constructed in 1958 and served as an F-Canyon low activity waste receipt tank beginning in 1959. From 1959 to 1977, Tank 18 received waste from F Canyon during multiple periods. Tank 18 also supported the 242-F Evaporator operations, as both a receiver of concentrated supernate and returned overheads, and as a feed tank for the evaporator. The plutonium isotopics in waste from F-Canyon would be typical for weapons grade plutonium, which is high in ${ }^{239} \mathrm{Pu}$ and ${ }^{240} \mathrm{Pu}$ and very low in ${ }^{238} \mathrm{Pu}$. In 1973, Tank 18 also received approximately 12,000 gallons of waste from H-Area Tank Farm (HTF) evaporator overheads and in 1974 approximately 719,000 gallons of waste from HTF were received. The isotopic distribution of $\mathrm{H}$-Canyon waste features high ${ }^{238} \mathrm{Pu}$, low ${ }^{239} \mathrm{Pu}$ and very little ${ }^{240} \mathrm{Pu}$.

This tank was designed as the sole conventional transfer route to exit F-Area Tank Farm (FTF) Type IV Tanks 17 through 20 (i.e., all waste being transferred out of Tanks 17, 19, and 20 went through Tank 18). In 1980 and 1981, Tank 18 received salt or sludge from Tanks 17, 19, and 20 waste removal activities. During this operation, some of the spent zeolite resins, which were originally confined to Tank 19, were transferred to, and settled in, Tank 18.

Supernate and bulk sludge removal from Tank 18 occurred in 1986. From about August of 1987 until early in 1991 about 28,000 to 35,000 gallons remained in the tank with no transfers into or out of the tank. Beginning in early 1991 several transfers of waste brought the level to about 89,000 gallons before transfers out of the tank provided a waste level of about 42,000 gallons by mid-1992, which remained at that level until March 1996. Additional waste transfers brought the volume of waste up to about 350,000 gallons and remained at that level until October of 2000 when waste transfers into and out of the tank maintained waste volumes between 350,000 and 630,000 gallons until November of 2001. From November 2001 until October 2002 the waste volume remained at 630,000 until transfers out of the tank reduced the waste volume to 319,000 gallons. The waste remained at this level until initial mechanical heel removal occurred in Tank 18 beginning in February 2003 using an Advanced Design Mixer Pump (ADMP). At the conclusion of heel removal, the tank waste volume was estimated at 5,000 to 8400 gallons. Subsequently, additional heel removal was performed in 2009 using a robotic crawler-based ultra-high pressure (UHP) eductor retrieval system, referred to as the mantis that reduced the volume of residual solids with associated interstitial supernate to approximately 4,000 gallons.

The large majority of the plutonium that transferred into Tank 18 was from F-Area and, therefore, would principally be comprised of two radioisotopes, ${ }^{239} \mathrm{Pu}$ and ${ }^{240} \mathrm{Pu}$. Since the initial waste introduced into Tank 18 contained only weapons grade plutonium, the sludge and residues at the bottom of the tank would likely reflect weapons grade plutonium isotopics. Tank 18 did receive significant quantities of waste from H-Area. Inventory estimates for Tank 18 indicate the tank received $56 \mathrm{~kg}$ of weapons grade plutonium and $1 \mathrm{~kg}$ of heat source plutonium, with most of the heat source plutonium received during the end of the operational period. ${ }^{3}$

\section{Calculations}

Calculation of mole ratios of iron to plutonium (see Table 1) and isotopic weight ratios of ${ }^{239} \mathrm{Pu}$ to

${ }^{238} \mathrm{Pu}$ used commercially available Microsoft Excel software as part of Microsoft Office 2010 Version 14.0.4761.1000. Specific activities of plutonium isotopes are those reported in "Compilation of Recent Radionuclide Data for Specific Activity, Specific Heat and Fission Product Yields”, Westinghouse Savannah River Company, Aiken SC, Technical Report WSRCTR-99-00344, October 1999. Calculation of $\mathrm{pH}$ values for the North and South Hemisphere liquid fractions separated from the Tank 18 samples received at SRNL in 2009 used 
Geochemist’s Workbench $^{\circledR}$ (geochemical modeling software), Release 8.0. Calculation of pressure from the grout fill in Tank 18 assumed the following, all of the force from the grout fill rested on the bottom of the tank, a maximum fill height of 45.2 feet, ${ }^{4}$ and a grout density of 136.6 $\mathrm{lb} / \mathrm{ft}^{3}{ }^{31}$ Outputs of all calculations are recorded in laboratory notebook WSRC-NB-2000-00135, pages $96-106$ assigned to D.T. Hobbs.

\section{Discussion}

\section{Forms of Plutonium in Tank 18 Residues}

Dissolution of spent fuel at SRS produces solutions of Pu(IV) in concentrated nitric acid. The oxidation state of the plutonium is typically controlled between $\mathrm{Pu}(\mathrm{IV})$ and $\mathrm{Pu}(\mathrm{III})$ to alter the extractability of the plutonium in the organic phase of the PUREX process. Residues from fuel reprocessing operations at SRS typically would be in the $\mathrm{Pu}(\mathrm{IV})$ oxidation state due to the high nitric acid concentration and lack of a reductant. Pu(IV) can be oxidized by nitric acid at high temperature such as would be present in the acid evaporators in the separations canyons. However, the presence of metal nitrate salts such as sodium nitrate, aluminum nitrate and uranyl nitrate inhibits $\mathrm{Pu}(\mathrm{IV})$ oxidation. Thus, $\mathrm{Pu}(\mathrm{IV})$ would be the expected predominant oxidation state of plutonium in residues from fuel reprocessing. ${ }^{5}$

Prior to the transfer of residues to the tank farm facilities, the residues are made strongly alkaline by the rapid addition of concentrated sodium hydroxide $(\mathrm{NaOH})$. The addition of the $\mathrm{NaOH}$ precipitates most of the metal ions in the waste solution as the respective metal hydroxide or hydrous metal oxide. For plutonium, the precipitated solid would be plutonium tetrahydroxide, $\mathrm{Pu}(\mathrm{OH})_{4}$ or hydrous plutonium oxide, $\mathrm{PuO}_{2} \mathrm{xH}_{2} \mathrm{O}$. Upon drying and calcination at high temperature, the $\mathrm{Pu}(\mathrm{OH})_{4}$ or $\mathrm{PuO}_{2} \mathrm{xH}_{2} \mathrm{O}$ converts to the dehydrated, crystalline form of plutonium dioxide, $\mathrm{PuO}_{2(\mathrm{c})}$, which is the most thermodynamically stable form of $\mathrm{Pu}(\mathrm{IV})$ oxide. ${ }^{5}$

Due to the high concentration of other metal ions such as iron, aluminum, manganese, and uranium compared to plutonium, the opportunity exists for the plutonium to be "coprecipitated" or "carried down" by the precipitated metal hydroxide or hydrous metal oxide during the addition of the sodium hydroxide. ${ }^{6}$ Coprecipitation of the plutonium can lead to one of three forms for the plutonium. Firstly, the plutonium can substitute for another metal ion in the lattice site of a crystal forming a mixed crystal phase. For example, $\mathrm{Pu}^{4+}$ substitutes for $\mathrm{Fe}^{3+}$ in $\mathrm{Fe}_{2} \mathrm{O}_{3} \mathrm{xH}_{2} \mathrm{O}$ or for $\mathrm{Mn}^{2+}$ in $\mathrm{MnO} \times \mathrm{xH}_{2} \mathrm{O}$. Secondly, the precipitated plutonium could be physically isolated or occluded within the metal hydroxide or hydrous metal oxide phase. In this case the plutonium adsorbs to the surface of the metal hydroxide as it forms, but does not become incorporated into the crystal lattice. The metal hydroxide or hydroxide metal oxide particle continues to grow in size isolating the impurity metal (i.e., plutonium). Thirdly, the plutonium can adsorb to the surface of the metal hydroxide or hydrous metal oxide precipitate after it has formed. These additional forms of plutonium effectively reduce the soluble fraction of plutonium in the system that would be in equilibrium with a pure $\mathrm{Pu}(\mathrm{OH})_{4}$ solid phase.

Coprecipitation of plutonium is well known and was the basis for the separation and purification of plutonium by a number of precipitating agents, ${ }^{7}$ including iron $^{8}$. Hobbs investigated the coprecipitation of uranium and plutonium from solutions featuring iron, aluminum, manganese, and nickel ion concentrations expected for residues from SRS fuel reprocessing operations. ${ }^{9}$ Testing results indicated that plutonium was effectively coprecipitated with iron or uranium when there was a large excess of the iron or uranium (e.g., Fe:Pu exceeds1500). Note that the form of plutonium in the coprecipitated solids was not determined in the study by Hobbs. Given the 
much larger ionic radius of $\mathrm{Pu}^{4+}(0.86-0.96 \AA)$ compared to $\mathrm{Fe}^{3+}(0.53 \AA)$, substitution of $\mathrm{Pu}^{4+}$ in a $\mathrm{Fe}^{3+}$ lattice site seems less likely than that of occlusion within or surface adsorption onto metal hydroxide or hydrous metal oxide particles. Lattice substitution of $\mathrm{Pu}^{4+}$ would be much more likely for $\mathrm{Mn}^{2+}$ in $\mathrm{MnO} \times \mathrm{H}_{2} \mathrm{O}$ as the ionic radius of $\mathrm{Mn}^{2+}$ is $0.91 \AA$, which is much more similar to that of $\mathrm{Pu}^{4+}$.

Elemental analysis of solid samples taken from Tank 18 showed the presence of significant concentrations of iron. ${ }^{10,11,12}$ From the elemental and radiochemical analyses, Table 1 provides the calculated Fe:Pu mole ratios for both the bottom samples and the scale sample taken from the wall. The Fe:Pu ratios for the samples from the bottom of the tank range from 1510 to 2890 suggesting that there is sufficient iron in these solids for the $\mathrm{Pu}$ to be effectively in a coprecipitated form. The very high ratios of Fe:Pu in the scale sample from the wall are likely skewed high due the presence of the iron oxide scale. If the plutonium is present as a coprecipitated solid, the plutonium would be expected to be dispersed uniformly throughout the solids with little or no individual particles of plutonium.

Recent scanning electron microscopy analysis of Tank 18 floor samples revealed the presence of discrete plutonium particles associated with an iron oxide matrix. ${ }^{22}$ The plutonium particles were spread unevenly within the iron oxide matrix. Furthermore the quantity of discrete plutonium particles did not appear to be sufficient in number to account for all of the plutonium in the sample based on concentrations determined from the chemical analysis of the Tank 18 samples. These findings suggest that plutonium is present as both discrete particles associated with an iron oxide matrix and as a coprecipitated form.

The coordination environment of the plutonium in a coprecipitated mixed metal oxide form would have iron or another metal in the second coordination shell if plutonium and iron or other metal share an oxygen atom (Pu in crystal lattice or coordinated to the oxygen of the metal oxide phase) or in the outer coordination shell if the plutonium is sorbed (e.g., hydrogen bonding as shown below). Confirmation of coordination environments of the plutonium may be possible by XAS spectroscopic techniques.

$$
(\mathrm{HO})_{3} \mathrm{Pu}-\mathrm{O}-\mathrm{H}^{\cdots \cdots} \mathrm{O}-\mathrm{M}-\mathrm{O} \quad \mathrm{M}=\text { metal such as Fe, } \mathrm{Mn}, \mathrm{Al}, \mathrm{U} \text {, etc. }
$$

$(\mathrm{HO})_{3} \mathrm{Pu}-\mathrm{O} \cdots \mathrm{H}-\mathrm{O}-\mathrm{M}-\mathrm{O}$

Table 1. Calculated Fe:Pu Ratios in Tank 18 Samples

$\begin{array}{cc}\text { Sample ID } & \text { Fe:Pu Mole Ratio } \\ \text { North Hemisphere } & 2640 \\ \text { South Hemisphere } & 1680 \\ \text { FTF-1 } & 1510 \\ \text { FTF-2 } & 1930 \\ \text { FTF-3 } & 2760 \\ \text { FTF-4 } & 2750 \\ \text { FTF-5 } & 2890 \\ \text { FTF-8-old } & 2670 \\ \text { 18-2 Scale (AR) } & 7590 \\ \text { 18-2 Scale (PF) } & 5960\end{array}$


The majority of plutonium that was received into Tank 18 during the operational period was in the form of freshly precipitated solids containing largely iron, aluminum and uranium. This would also include colloidal plutonium oxides. A much smaller fraction of plutonium entered the tank in a dissolved form. Since the tank received a variety of waste including evaporator concentrates, precipitation of plutonium may also have occurred due to changes in the bulk solution composition upon the introduction and mixing of waste solutions having different chemical compositions. Plutonium is known to readily adsorb onto the surface of solids such as iron oxide and, thus, some of the dissolved plutonium may have adsorbed on the surface of particles. ${ }^{13}$ This could include the surfaces of the steel tank which have a film of iron oxide on the surface from exposure to water and other deposits that have formed on the steel surface. Furthermore, during the operation history, the tank received concentrated evaporator supernate, which upon cooling produced saltcake. Dissolved plutonium may have sorbed to or become occluded in salts that deposited.

Readily dissolvable salts and the plutonium associated with these salts were likely removed from Tank 18 during waste removal and subsequent heel removal operations, which contacted the salts with large quantity of water. Any remaining salts and the plutonium associated with these salts are very sparingly soluble in inhibited water. During residual heel removal in 2003 and 2009, the remaining solids were contacted with large quantities of inhibited water. This operation would serve to shift the equilibrium and dissolve $\mathrm{Pu}(\mathrm{IV})$ from the various solid phases containing plutonium. It would be expected that pure $\mathrm{PuO}_{2(\mathrm{am}, \mathrm{hyd})}$ and $\mathrm{Pu}(\mathrm{IV})$ sorbed on particle surfaces would dissolve before plutonium that is substituted in crystal lattice sites or occluded within mixed metal oxide phases. However, no experimental data exists to confirm or quantify if such a selective dissolution mechanism occurred during bulk waste and heel removal campaigns in Tank 18.

The total plutonium concentrations in the liquid samples isolated from the Tank 18 samples taken in 2009 measured $1.3 \times 10^{-8}$ and $2.6 \times 10^{-8} \mathrm{M}$ for the North and South Hemisphere samples, respectively. ${ }^{10}$ The reported solubility of $\mathrm{PuO}_{2(\mathrm{am}, \mathrm{hyd})}$ in alkaline solutions ranges from about $1 \mathrm{x}$ $10^{-11}$ to $2 \times 10^{-9} \mathrm{M}^{14,15,16}$ Coprecipitation of plutonium during the initial $\mathrm{pH}$ adjustment of the residues from fuel reprocessing would be expected to produce a solution phase with a lower concentration of plutonium than that for a solution in equilibrium with that of the plutonium solid phase (e.g., $\mathrm{PuO}_{2(\mathrm{am}, \mathrm{hyd})}$ ). Thus, the measured plutonium liquid phase concentrations are well above the predicted solubilities for $\mathrm{PuO}_{2 \text { (am,hyd) }}$ and coprecipitated $\mathrm{Pu}(\mathrm{IV})$. Some fraction of measured plutonium in the liquid phases may be due to the presence of colloidal $\mathrm{PuO}_{2}$ that is small enough to pass through the 0.45 -micron filter used to separate the solid and liquid phases. An indication of the presence of colloidal $\mathrm{PuO}_{2}$ could be assessed by filtering the liquids through a series of filter media with finer pore diameters.

Most of the waste that transferred into Tank 18 was from F-Canyon fuel reprocessing operations and, therefore, should have a plutonium isotopic signature typical of weapons grade plutonium (i.e., high in ${ }^{239,240} \mathrm{Pu}$ ). Analyses of samples taken from the floor of Tank 18 after bulk waste and heel removal indicate that ${ }^{239} \mathrm{Pu}$ and ${ }^{240} \mathrm{Pu}$ are the principal plutonium isotopes on a mass basis. ${ }^{10,11}$ Furthermore, the weight ratio of ${ }^{239} \mathrm{Pu}$ to ${ }^{240} \mathrm{Pu}$ in the solid samples is similar to that expected for weapons grade plutonium. However, the ${ }^{238} \mathrm{Pu}$ concentration is higher than that expected for purely weapons grade plutonium. This is not unexpected since Tank 18 did receive wastes containing heat source plutonium beginning in 1973.

Analysis of samples taken from the wall in Tank 18 revealed a higher abundance of ${ }^{238} \mathrm{Pu}$ compared to that measured in the floor samples. This is not unexpected since most of the ${ }^{238} \mathrm{Pu}$ transferred into Tank 18 occurred during the later operational stage. Interestingly, the ${ }^{238} \mathrm{Pu}$ 
content in the three wall samples correlated with elevation of sample. ${ }^{12}$ The weight ratio of ${ }^{239} \mathrm{Pu}$ to ${ }^{238} \mathrm{Pu}$ measured between 561 and 777 for the solids obtained from the bottom of the tank with the exception of a scrape sample taken from the NE riser in 2009, which measured a weight ratio of 269. Scale samples (Sample 18-2) taken from the wall at approximately 6-7 feet, a wall sample taken at about 10 - 12 feet (Sample ID SP4), and wall sample taken at about 17 feet (Sample 18-1) measured ${ }^{239} \mathrm{Pu}$ to ${ }^{238} \mathrm{Pu}$ weight ratios of $175,32.1$ and 14.7 , respectively. The higher ${ }^{238} \mathrm{Pu}$ content with the wall samples suggests that deposition of the ${ }^{238} \mathrm{Pu}$ likely occurred from solution. Possible deposition mechanisms would include adsorption and evaporative deposition. The variance in ${ }^{238} \mathrm{Pu}$ content with elevation may reflect the levels of liquid that contacted the wall during bulk removal and heel retrieval events.

Hydrogen is continually produced during the storage of high level nuclear wastes (HLW) due the radiolysis of water. Consequently, the HLW tanks at SRS are equipped with active ventilation systems to prevent the hydrogen concentrations from reaching the lower flammable limit. Air containing carbon dioxide is continuously pumped into the HLW tanks. At the vapor-liquid interface, atmospheric carbon dioxide is absorbed and reacts with hydroxide to form carbonate and bicarbonate. At steady-state conditions, $\mathrm{CO}_{2}$ absorption can reduce the $\mathrm{pH}$ to around $9-10$ in dilute solutions. ${ }^{17,18}$ During long periods of storage at relatively low waste volume and no transfers of wastes into the tank, the free hydroxide in the liquid phase of the waste would be expected to have been converted to carbonate and bicarbonate. Such a period occurred between 2003 and 2009. This could also include other metal hydroxides that are present in the solution (e.g., aluminum hydroxide).

Carbonate is an effective complexing agent for $\mathrm{Pu}(\mathrm{IV})$. Thus, some fraction of the $\mathrm{Pu}(\mathrm{OH})_{4(\mathrm{a})}$ or

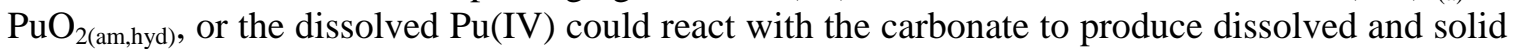
phases containing carbonates. As long as the hydroxide concentration is very high $(\mathrm{pH}>13)$, hydroxide complexes will dominant. However, at low hydroxide $(\mathrm{pH}<13)$ and high carbonate concentrations, formation of a mixed carbonate complex such as $\mathrm{PuO}\left(\mathrm{CO}_{3}\right)_{\text {(am,hyd) }}$ could occur.

Several studies have shown evidence for the formation of carbonate complexes of $\mathrm{Pu}(\mathrm{IV})$. For example, Kim, et. al investigated the solubility of crystalline $\mathrm{PuO}_{2}$ in alkaline carbonate solutions. ${ }^{14}$ They reported that the plutonium solubility decreased with increasing $\mathrm{pH}$ and reached a minimum of $2 \times 10^{-9} \mathrm{M}$ at $\mathrm{pH} 10$ and carbonate concentration of $3 \times 10^{-3} \mathrm{M}$. They also reported that the plutonium solubility increased sharply with increasing carbonate concentration. For example, at a carbonate concentration of about $0.032 \mathrm{M}$ and $\mathrm{pH}$ of about 11.0, the plutonium solubility was reported to be $1 \times 10^{-6} \mathrm{M}$. They attributed the sharp change in solubility due to the transformation of the solid $\mathrm{PuO}_{2}$ to a plutonium hydroxy-carbonate phase, $\mathrm{Pu}(\mathrm{OH})_{2}\left(\mathrm{CO}_{3}\right)_{(\mathrm{s})}$.

Yamaguchi, et. al also investigated the solubility of $\mathrm{Pu}(\mathrm{IV})$ in aqueous carbonate solutions. ${ }^{19}$ They reported that $\mathrm{PuO}\left(\mathrm{CO}_{3}\right) \mathrm{xH}_{2} \mathrm{O}_{(\mathrm{s})}$ is the solid phase in equilibrium with $\mathrm{Pu}(\mathrm{OH})_{2}\left(\mathrm{CO}_{3}\right)_{2}{ }^{2-}$ over the $\mathrm{pH}$ range of 9.4 to 10.1 and $\mathrm{Pu}(\mathrm{OH})_{4}\left(\mathrm{CO}_{3}\right)_{2}{ }^{4-}$ in $\mathrm{pH} 12$ and 13 solutions. These studies were in low ionic strength solutions and with a total carbonate concentration of $<0.1 \mathrm{M}$. Rai, et. al also investigated the solubility of $\mathrm{PuO}_{2(\mathrm{am}, \mathrm{hyd})}$ over the concentration range of 0.1 to 6.2 molal potassium carbonate. ${ }^{20}$ These authors reported that $\mathrm{Pu}\left(\mathrm{CO}_{3}\right)_{5}{ }^{6-}$ is the dominant solution species in high carbonate and bicarbonate concentrations and $\mathrm{Pu}(\mathrm{OH})_{2}\left(\mathrm{CO}_{3}\right)_{2}{ }^{2-}$ is the dominant solution species at low bicarbonate concentration.

Oji, et. al reported carbonate concentrations of 0.040 and $0.044 \mathrm{M}$ in liquids isolated from Tank 18 samples taken in 2009 during heel removal with the mantis. ${ }^{10}$ They also reported that the wet solids from these samples contained leachable carbonate. The high carbonate concentrations in 
both the liquid fraction samples and in the wet solids leachates are consistent with reduced free hydroxide concentrations and increased carbonate/bicarbonate concentrations in the Tank 18 heel residues at the time these samples were taken. Measurement of the free hydroxide or $\mathrm{pH}$ in the Tank 18 liquid samples was not performed. However, thermodynamic calculations using Geochemistry Workbench and the measured concentrations of anions and cations indicate $\mathrm{pH}$ values of 10.19 and 10.24 for the North and South Hemisphere liquid fraction samples. Furthermore, the concentrations of uranium in the liquid fraction samples measured 752 (North Hemisphere) and $657 \mathrm{mg} / \mathrm{L}$ (South Hemisphere). These very high concentrations of uranium are consistent with solutions that are high in carbonate and low in hydroxide. ${ }^{21} \quad \mathrm{X}$-ray diffraction analysis identified a uranyl carbonate phase, $\mathrm{Na}_{4} \mathrm{UO}_{2}\left(\mathrm{CO}_{3}\right)_{3}$, as a major crystalline component of the Tank 18 solids. $^{22}$ Given these findings, some fraction of the dissolved plutonium and solid phase plutonium in Tank 18 has likely been converted into a $\mathrm{Pu}(\mathrm{IV})$ carbonate complex such as $\mathrm{Pu}(\mathrm{OH})_{2}\left(\mathrm{CO}_{3}\right)_{(\mathrm{s})}$. or $\mathrm{PuO}\left(\mathrm{CO}_{3}\right) \mathrm{xH}_{2} \mathrm{O}_{(\mathrm{s})}$.

Additional evidence of this transformation is inferred from the measured plutonium concentrations in the liquid fractions of the Tank 18 samples. If the transformation of the $\mathrm{PuO}_{2(\mathrm{~s})}$ to a $\mathrm{PuO}\left(\mathrm{CO}_{3}\right) \mathrm{xH}_{2} \mathrm{O}_{(\mathrm{s})}$ took place during the time period between heel removal in 2003 with the ADMP and heel removal activities in 2009 with the mantis, the expected plutonium concentration in equilibrium with the carbonate phase would be about $1 \times 10^{-6} \mathrm{M}$ at a $\mathrm{pH}$ of 9.8 . ${ }^{16}$ Dilution of the liquid phase composition would be expected during the heel removal operations in 2003 and 2009. The measured concentrations in heel residues at the conclusion of the 2009 removal operations measured $1.5 \times 10^{-8}$ and $2.9 \times 10^{-8} \mathrm{M}$, which are about 50 times lower than the reported solubility value of $1 \times 10^{-6} \mathrm{M}$ at 9.8. Confirmation of the presence of a plutonium carbonate solid phase in the Tank 18 solids would confirm this hypothesis. XAS analysis of the solids should be able to determine if the plutonium contains coordinated carbonate.

At neutral and alkaline conditions, there are reports that $\mathrm{Pu}(\mathrm{IV}), \mathrm{Pu}(\mathrm{V})$ and $\mathrm{Pu}(\mathrm{VI})$ species can be present in solution. Oxidation of $\mathrm{Pu}(\mathrm{IV})$ to the higher oxidation state likely results from reaction with products from the radiolysis of water and, if present, with oxygen from the air. $\mathrm{Pu}(\mathrm{V})$ is not stable at neutral and weakly alkaline conditions ( $<6 \mathrm{M}$ hydroxide) and, therefore, will disproportionate into $\mathrm{Pu}(\mathrm{IV})$ and $\mathrm{Pu}(\mathrm{VI})$. Since the free hydroxide concentration in the Tank 18 residues is suspected to be well below $5 \mathrm{M}, \mathrm{Pu}(\mathrm{V})$ would not be expected to be present in significant quantities in Tank 18. Pu(VI) is relatively stable under neutral and weakly alkaline conditions in the absence of reducing agents. The overall fraction of $\mathrm{Pu}(\mathrm{IV})$ and $\mathrm{Pu}(\mathrm{VI})$ that would be present would be controlled by the overall redox properties of the residues.

\section{Aging of Plutonium in Tank 18}

Precipitated or microcrystalline solids are well known to transform into more crystalline and lower surface area solids by a spontaneous process known as Ostwald ripening. ${ }^{23,24}$ For metal hydroxides or hydrous metal oxides, the ripening process sheds water from the crystalline structure resulting in a less hydrated solid phase. Thus, in the case of $\mathrm{Pu}(\mathrm{OH})_{4}$, dehydration and crystallization would produce crystalline $\mathrm{PuO}_{2}$ as shown in equation 1 . The increased crystallinity results in a lower Gibbs energy for the system and lower solubility for the more crystalline solid phase.

$$
\mathrm{Pu}(\mathrm{OH})_{4(\mathrm{am})}=\mathrm{PuO}_{2(\mathrm{c})}+2 \mathrm{H}_{2} \mathrm{O}
$$


This has shown to be the case for $\mathrm{Pu}(\mathrm{OH})_{4(\mathrm{am})}$ and $\mathrm{PuO}_{2(\mathrm{c})}$. For example, Rai, et. al reported that the solubility of $\mathrm{PuO}_{2(\mathrm{c})}$ measured about two orders of magnitude lower than that of $\mathrm{Pu}(\mathrm{OH})_{4(\mathrm{am})}$ in tests with solutions ranging between $\mathrm{pH} 3$ and $7.5 .^{25}$

The rate of ripening depends strongly on environmental conditions such as temperature as well as the solubility of the metal ion. At low temperature and with substances that exhibit low solubility, the ripening process is very slow. The rate of ripening is significantly increased by increasing temperature. Heating at high temperature under pressure (i.e., hydrothermal treatment) is commonly used to produce crystalline metal oxides. ${ }^{26}$ Typically, as long as the solids remain in contact with water, the solids will retain some amount of water in crystalline matrix. Formation of completely dehydrated crystalline solids typically requires heating in an open system at very high temperature. For example, the preparation of $\mathrm{PuO}_{2}$ from plutonium hydroxide employs a calcination step in which dried solids are heated from 250 to $750{ }^{\circ} \mathrm{C}$ for $0.75-2.0$ hours. ${ }^{27}$

The operational history of Tank 18 does not include temperatures close to the calcination temperatures used in the preparation of $\mathrm{PuO}_{2}$. Furthermore, there has always been a high water content in the tank during waste storage and bulk waste retrieval. After heel removal using the mantis, photographs of the tank interior revealed the appearance of "dry" solids while the forced air ventilation system operated. ${ }^{28}$ More recent photographs, taken after the ventilation system was placed in a standby mode, have revealed the appearance of "wet" solids. ${ }^{29}$ Thus, the heel residues in Tank 18 currently continue to contain water. Upon grouting of the tank for closure, there will continue to be water in contact with the waste, although the concentration of water will be reduced compared to that during the operational and waste removal periods.

Grouting the tank will increase the pressure and produce a transitory increase in temperature due the heat of hydration released during curing of the wet grout. The current requirements for the grout formulation include a requirement that the temperature of the grout not exceed $65^{\circ} \mathrm{C}$ during curing. $^{30}$ Experiments at SRNL indicated that the recommended grout formulation measured a semi-adiabatic temperature rise of $23{ }^{\circ} \mathrm{C}$, which occurred after 82 hours of curing. ${ }^{31}$ Thus, the maximum expected temperature that the waste residues would experience during grouting of the tank would be $65^{\circ} \mathrm{C}$. The weight of the grout used to fill the tank will exert a pressure on the tank residues. The estimated maximum pressure on the residues after completely filling the tank with grout is $2.9 \mathrm{~atm}$.

The combination of heat from grout curing and increased pressure from the weight of the grout will produce hydrothermal-like conditions for the residues, which would favor the formation of more crystalline metal oxide phases. However, the low temperature $\left(65{ }^{\circ} \mathrm{C}\right)$ and pressure $(2.9 \mathrm{~atm})$ are well below conditions typically used to prepare crystalline metal oxides. ${ }^{26}$ Furthermore, the temperature rise is transitory to the curing phase and will decrease quickly after curing and reach a much lower value close to the surrounding ground temperature. Thus, the environmental conditions produced during the filling of the tank with grout and continuing during the closure phase are not expected to produce a significant impact on converting the plutonium to a more crystalline form. After closure, the residual waste solids will continue to be in contact with water from the pore water in the grout. Thus, there is no identifiable mechanism during the closure period that would completely remove water from the system and heat the waste to sufficient high temperature to convert the plutonium to completely crystalline $\mathrm{PuO}_{2}$.

A review of the literature revealed a few studies on the aging of plutonium-containing solids. Rai

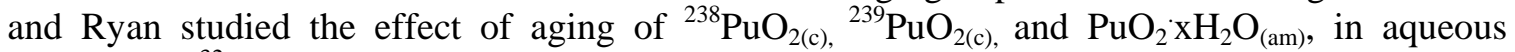
suspensions. ${ }^{32}$ They reported that the crystalline $\mathrm{PuO}_{2(\mathrm{c})}$ solids converted to less crystalline solids with properties between those of the true crystalline $\mathrm{PuO}_{2}$ and those of fresh $\mathrm{PuO}_{2} \mathrm{xH}_{2} \mathrm{O}_{(\mathrm{a})}$ or 
$\mathrm{Pu}(\mathrm{OH})_{4(\mathrm{am})}$. Furthermore, after 1300 days, $\mathrm{PuO}_{2} \mathrm{xH}_{2} \mathrm{O}_{(\mathrm{am})}$ had developed some crystallinity, but had not changed completely to $\mathrm{PuO}_{2(\mathrm{c})}$. They attributed these findings to a combination of aging in which dehydration and crystallization leading to $\mathrm{PuO}_{2(\mathrm{c})}$ is opposed by radiolytic effects.

Kim and Kanellakopulos investigated the solubility products of $\mathrm{PuO}_{2(\mathrm{c})}$ and $\mathrm{Pu}(\mathrm{OH})_{4(\mathrm{am})}$ in $1 \mathrm{M}$ $\mathrm{HClO}_{4}$ and at different $\mathrm{pH}$ values from 1.09 to $3.68 .^{33}$ For $\mathrm{Pu}(\mathrm{OH})_{4(\mathrm{am})}$, they reported that equilibrium is reached after 45 days in $1 \mathrm{M} \mathrm{HClO}_{4}$ and observed no further changes in the $\mathrm{Pu}^{4+}$ concentration between 45 and 125 days. At the higher $\mathrm{pH}$ conditions, about one-half of the $\mathrm{Pu}$ concentration in solution is attributed to $\mathrm{Pu}(\mathrm{IV})$ colloids. Furthermore, there is evidence that $\mathrm{Pu}^{3+}$, $\mathrm{PuO}_{2}{ }^{+}$, and $\mathrm{PuO}_{2}{ }^{2+}$ are present in the solution. For $\mathrm{PuO}_{2(\mathrm{c})}$, the concentration of $\mathrm{Pu}^{4+}$ in equilibrium with the solids is more than two orders of magnitude lower than that observed for $\mathrm{Pu}(\mathrm{OH})_{4(\mathrm{am})} \cdot \mathrm{Pu}^{3+}$ and $\mathrm{PuO}_{2}{ }^{2+}$, but not $\mathrm{PuO}_{2}{ }^{+}$and $\mathrm{Pu}(\mathrm{IV})$ colloids, were observed in the solution. The results for $\mathrm{PuO}_{2(\mathrm{c})}$ are consistent with the solids undergoing hydration on the surface to produce a $\mathrm{Pu}(\mathrm{OH})_{4(\mathrm{am})}$ or $\mathrm{PuO}_{2 \text { (am,hyd) }}$ layer.

During the closure period, Ostwald ripening remains a viable mechanism to form more crystalline plutonium solids due to the presence of pore water contacting the $\mathrm{PuO}_{2 \text { (am,hyd) }}$ and coprecipitated forms of plutonium. However, the available water after tank closure is significantly reduced compared to that during the operational and cleaning periods. Since Ostwald ripening depends on dissolution of the amorphous solids into and deposition from the liquid phase, the reduced quantity of water will effectively decrease the rate of forming crystalline $\mathrm{PuO}_{2}$. Other amorphous metal oxide phases will also compete with plutonium for available water in the ripening process. Thus, formation of crystalline $\mathrm{PuO}_{2}$ by Ostwald ripening after tank closure would be expected to be an extremely slow process.

Given these studies, the $\mathrm{PuO}_{2 \text { (am,hyd) }}$ in Tank 18, whether as separate solid phases, adsorbed on the surface of other solids, or incorporated in coprecipitated solid phases, would be expected to undergo Ostwald ripening, albeit at a very slow rate, to produce a more crystalline solid phase. This is also true for the other amorphous metal hydroxides and hydrous metal oxides in the residues such as iron and aluminum. However, it would not be expected that the ripening process would continue to the completely dehydrated and crystalline $\mathrm{PuO}_{2(\mathrm{c})}$ form. It is very likely, that the plutonium-containing solids would retain a surface layer of $\mathrm{PuO}_{2(\mathrm{am}, \mathrm{hyd})}$ due to the continual presence of water and reactions with products from the radiolysis of water.

The grout formulation planned for Tank 18 features a material with high alkalinity and low carbonate concentration. ${ }^{30}$ Consequently, interaction of the grout with the plutonium in the tank residues would be expected to increase the $\mathrm{pH}$. Given the low carbonate concentration in the grout initially, it would be expected that carbonate will diffuse away from the waste solids into the grout. The increase in $\mathrm{pH}$ and decrease in the carbonate concentration will serve to convert plutonium carbonate phases, $\mathrm{Pu}(\mathrm{OH})_{2}\left(\mathrm{CO}_{3}\right)_{(\mathrm{s})}$ or $\mathrm{PuO}\left(\mathrm{CO}_{3}\right) \mathrm{xH}_{2} \mathrm{O}_{(\mathrm{s})}$ back into plutonium hydroxide, $\mathrm{Pu}(\mathrm{OH})_{4(\mathrm{am})}$ or hydrous plutonium oxide, $\mathrm{PuO}_{2(\mathrm{am} \text {,hyd) }}$ Confirmation of this transformation could be determined experimentally by contacting $\mathrm{Pu}(\mathrm{OH})_{2}\left(\mathrm{CO}_{3}\right)_{(\mathrm{s})}$ or $\mathrm{PuO}\left(\mathrm{CO}_{3}\right) \mathrm{xH}_{2} \mathrm{O}_{(\mathrm{s})}$ with the grout and monitoring the $\mathrm{pH}$ and the presence of the plutonium carbonate phase with time. Furthermore, reductants present in the grout will initially maintain a reducing environment that would eliminate the oxidation of plutonium to more soluble $\mathrm{Pu}(\mathrm{V})$ and $\mathrm{Pu}(\mathrm{VI})$ forms. 


\section{Conclusions and Recommendations}

Based on a review of the operational history of Tank 18 and a literature review on alkaline plutonium chemistry, it is concluded that $\mathrm{PuO}_{2(\mathrm{am}, \mathrm{hyd})}$, coprecipitated plutonium and $\mathrm{PuO}\left(\mathrm{CO}_{3}\right)_{(\mathrm{am}, \mathrm{hyd})}$ are the dominant forms of plutonium in the residual waste in Tank 18 after heel removal activities completed in 2009. The coprecipitated plutonium would include $\mathrm{Pu}^{4+}$ that has been substituted for other metal ions in crystal lattice sites, $\mathrm{Pu}^{4+}$ occluded within hydrous metal oxide particles and $\mathrm{Pu}^{4+}$ adsorbed onto the surface of hydrous metal oxide particles. The adsorbed plutonium could include both inner sphere coordination and outer sphere coordination of the plutonium. Upon interaction of the grout with the waste residues it is expected that the

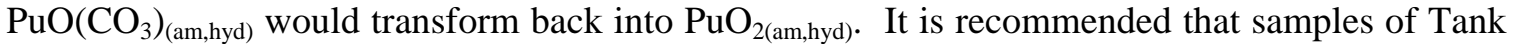
18 solids be analyzed by XAS techniques to confirm the coordination environment of the plutonium. If the presence of $\mathrm{PuO}\left(\mathrm{CO}_{3}\right)_{(\mathrm{am}, \mathrm{hyd})}$ is confirmed by XAS, it is recommended that experiments be conducted to determine if plutonium carbonates are transformed back into $\mathrm{PuO}_{2 \text { (am,hyd) }}$ upon contact with grout.

Although crystalline plutonium dioxide is the more stable thermodynamic state, the low temperature and high water content of the waste during the operating and heel removal periods in Tank 18 have limited the transformation of the plutonium hydroxide into crystalline plutonium dioxide. During the tank closure period of thousands of years, transformation into a more crystalline plutonium dioxide form would be expected. However, the continuing presence of water, reaction with water radiolysis products, and low temperatures will limit the transformation, and will likely maintain an amorphous $\mathrm{Pu}(\mathrm{OH})_{4}$ or $\mathrm{PuO}_{2 \text { (am,hyd) }}$ form on the surface of any crystalline plutonium dioxide produced after tank closure.

These findings should apply in general to residues in other waste tanks. However, the operational history of other waste tanks should be evaluated for specific conditions and unique operations (e.g., acid cleaning with oxalic acid) that could alter the form of plutonium in heel residues. Based on the operational history of other tanks, characterization of samples from the heel residues in those tanks would be appropriate to confirm the form of plutonium. 


\section{References}

1 Industrial Wastewater Closure Module for the Liquid Waste Tanks 18 and 19 F-Area Tank Farm, Savannah River Site, Predecisional Deliberative Document Requested by DOE, SRR-CWDA-101100003, Revision B, Prepared by Savannah River Remediation LLC, Aiken, SC, June 2011.

${ }^{2}$ Thomas, J.L. Tanks 17 - 20 Volume Histories, Westinghouse Savannah River Company, Aiken, SC, Technical Report WSRC-TR-2004-00284, rev. 1, September 16, 2004.

${ }^{3}$ Sludge1.5 Database, Tank 18 Spreadsheet, WG17 Server, Savannah River Remediation, Aiken, SC, January 2012.

${ }^{4}$ Draft Section 3116 Determination for Closure of Tank 19 and Tank 18 at the Savannah River Site, DOEWD-2005-002, Revision 0, September 30, 2005.

${ }^{5}$ Cleveland, J.M. The Chemistry of Plutonium, American Nuclear Society, La Grange Park, IL, 1979, Chapter 9, p 311.

${ }^{6}$ Kolthoff, I. J. Phys. Chem., 1932, 36(3), 860 - 881.

7 Weigel, F.; Katz, J.J.; Seaborg, G.T. Chapter 7 - Plutonium. In The Chemistry of the Actinide Elements; Katz, J.J.; Seaborg, G.T.; Morss, L.R., Eds., Chapman and Hall, London $2^{\text {nd }}$ Edition, Volume 1, 1986, pp $509-516$.

${ }^{8}$ United Kingdom Atomic Energy Authority, “Process for Separating Plutonium by Hydroxides”, U.K. Patent 859191, January 16, 1961.

${ }^{9}$ Hobbs, D.T. (1998) Nuclear Technology, 128, 103 - 112.

${ }^{10}$ Oji, L.N.; DiPrete, D.; Click, D.R. "Characterization of the Tank 18F Samples, Technical Report SRNLSTI-2009-00625, Rev. 0, Savannah River National Laboratory, Aiken, SC, December 17, 2009.

${ }^{11}$ Oji, L.N.; DiPrete, D.; Coleman, CJ. "Characterization of Additional Tank 18F Samples, Technical Report SRNL-STI-2010-00386, Rev. 0, Savannah River National Laboratory, Aiken, SC, September 2, 2010.

${ }^{12}$ Hay, M.S.; Click, D.R.; DiPrete, D.P.; DiPrete, C.C. "Characterization of Tank 18F Wall and Scale Samples”, Technical Report SRNL-STI-2009-00802, Rev. 0, Savannah River National Laboratory, Aiken, SC, March, 2010.

${ }^{13}$ Advances in Plutonium Chemistry 1967 - 2000, Hoffman, D.C.; Ed. American Nuclear Society, La Grange Park, IL, 2002, Chapters 6 and 7.

${ }^{14}$ Kim, J.I.; Lierse, C.H.; Baumgartner, F. Complexation of the Plutonium(IV) Ion in Carbonate-Bicar bonate Solutions in Plutonium Chemistry, Carnall, W.T. and Choppin, G.R., Eds. ACS Symposium Series 216, Washington, DC, 1983, pp 317 - 334.

${ }^{15}$ Neck, V.; Kim, J.I. Radiochimica Acta (2001), 89, 1 - 16.

${ }^{16}$ Yamaguchi, T.; Sakamoto, Y.; Ohnuki, T. (1994) Radiochimica Acta, 66/67, 9 - 14.

${ }^{17}$ Hobbs, D.T.; Wallace, R.M. "Hydroxide Depletion in Waste Storage Tank by Reaction with Carbon Dioxide”, Technical Report DPST-85-846, Savannah River Laboratory, Aiken, SC, October 14, 1985.

${ }^{18}$ Hobbs, D.T. “Absorption of Carbon Dioxide in Waste Tanks”, Technical Report DPST-86-735, Savannah River Laboratory, Aiken, SC, October 21, 1986.

${ }^{19}$ Yamaguchi, T.; Sakamoto, Y.; Ohnuki, T. (1994) Radiochimica Acta, 66/67, 9 - 14.

${ }^{20}$ Rai, D.; Hess, N.J.; Felmy, A.R.; Moore, D.A.; Yui, M.; Vitorge, P. (1999) Radiochimica Acta, 86, 89 100

${ }^{21}$ Hobbs, D.T. and Edwards, T.B. "Solubility of Uranium in Alkaline Salt Solutions (U)”, Savannah River Technology Center, Aiken, SC, Technical Report WSRC-TR-93-454, Revision 0, March 29, 1994.

${ }^{22}$ Hay, M.S., O’Rourke, P.E., Ajo, H.M. "Summary of XRD and SEM Analysis of Tank 18 Samples”, Savannah River National Laboratory, Aiken, SC, Memorandum Report SRNL-L3100-2012-00017, February, 2012,

${ }^{23}$ Mullin, J. W. 2003. Crystallization and Precipitation, in Ullman's Encyclopedia of Industrial Chemistry, Wiley-VCH. Verlag GmbH, Weinheim, Germany, Published online 15Jan 2003, DOI:10.1002/14356007.b02_03.

${ }^{24}$ Schüth, F. (2008) General Principles for the Synthesis and Modification of Porous Materials, in Handbook of Porous Solids (eds F. Schüth, K. S. W. Sing and J. Weitkamp), Wiley-VCH Verlag GmbH, Weinheim, Germany. DOI: 10.1002/9783527618286.ch16.

${ }^{25}$ See Fig 6.13, in reference13. 
${ }^{26}$ Byrappa, K. 2005. Hydrothermal Processing. Kirk-Othmer Encyclopedia of Chemical Technology.

${ }^{27}$ Weigel, F.; Katz, J.J.; Seaborg, G.T. Chapter 7 - Plutonium. In The Chemistry of the Actinide Elements; Katz, J.J.; Seaborg, G.T.; Morss, L.R., Eds., Chapman and Hall, London $2^{\text {nd }}$ Edition, Volume 1, 1986, pp $685-687$.

${ }^{28}$ Chandler, T.L. “Tank 18 Floor Sample Location Verification Document”, Savannah River Remediation, Aiken, SC, Technical Report SRR-LWE-2009-00129, rev. 1, January 11, 2010.

${ }^{29}$ Video inspections of Tank 18 interior performed by Savannah River Remediation.

${ }^{30}$ Stefanko, D. and Langton, C.A. "Tank 18 and 19-F Structural Flowable Grout Fill Material Evaluation and Recommendations", Savannah River National Laboratory, Aiken, SC, Technical Report SRNL-STI2011-00551, Rev. 0, September 2011.

${ }^{31}$ Stefanko, D. and Langton, C.A. “Tank 18-F and 19-F Tank Fill Grout Scale Up Test Summary”, Savannah River National Laboratory, Aiken, SC, Technical Report SRNL-STI-2011-00749, Rev. 0, December 2011.

${ }^{32}$ Rai, D.; Ryan, J.L. (1982) Radiochimica Acta, 30, 213 - 216.

${ }^{33}$ Kim, J.I; Kanellakopulos, B. (1989), Radiochimica Acta, 48, 145 - 150. 
Distribution:

H.H. Burns, 773-41A

D. A. Crowley, 773-43A

M.E. Denham, 773-42A

S. D. Fink, 773-A

J.C. Griffin, 773-A

M.S. Hay, 773-42A

D.T. Hobbs, 773-A

D.I. Kaplan, 773-43A

P. R. Jackson, 703-46A

M.H. Layton, 705-1C

S.L. Marra, 773-A

F.M. Pennebaker, 773-42A

S.H. Reboul, 773-A

K.H. Rosenberger, 705-1C

S.A. Thomas, 701-C

J.C. Tseng, 705-1C

W.R. Wilmarth, 773-A 